\title{
A palavra como remissão da alma (Portugal no século XV)
}

\section{Eduardo Lima de Souza*}

DOI: 10.11606/issn.2318-8855.v10i2p603-623

Resumo: Um dos primeiros efeitos da imprensa de caracteres móveis, em Portugal, na segunda metade do século XV, foi a divulgação de obras de piedade popular, tais como os tratados religiosos e de moral prática. Essas obras concentravam diversas prédicas para iniciar os cristãos nos rudimentos da fé católica a partir, sobretudo, dos pecados mortais, dos sentidos do corpo e dos dez mandamentos da lei de Deus. 0 presente artigo tem como objetivo analisar o peso conferido, especificamente, às boas palavras, igualmente sustentadas sobre a explicitação na forma oral, nomeadamente no momento da confissão auricular e individual, expressos nos manuais impressos da doutrina cristã, de meados do século XV.

Palavras-chaves: Remissão, Palavra, Portugal.

* Graduado em História pela Universidade Estadual Paulista "Júlio de Mesquita Filho" - Câmpus de Franca; membro do grupo temático Escritos sobre os Novos Mundos: uma história da construção de valores morais em língua portuguesa (FAPESP - Processo 2013/14786-6). E-mail: eduardo.lima@unesp.br 


\section{O poder na Idade Média}

Eduardo Lima de Souza

Segundo um dos principais doutores da Igreja, Santo Ambrósio (ca. 340-397), a "penitência é a dor de coração e amargura da alma pelos pecados que cada um cometeu" (SANCHEZ, 2010, p. 217), e ainda é doer-se "de todos seus pecados com vontade de não retornar mais a eles, nem os cometer" (SANCHEZ, 2010, p. 217). Segundo as obras prescritivas, para tornar efetiva a penitência, as palavras tinham sido dadas por Deus como forma de cura das enfermidades espirituais. Sustentado em tais ensinamentos, o sacramento da penitência foi instituído como uma sentença real que produzia, através do dom das palavras, o efeito causal da remissão dos pecados, já que Cristo deu aos homens a plenitude de confessar os próprios pecados e a seus discípulos, a autoridade de perdoá-los (PRODI, 2005, p. 74).

Obras prescritivas, tal como o referido Sacramental, dão testemunho particularmente forte acerca do poder e da eficácia das palavras, sua força persuasiva e terapêutica exaltava a prática da confissão, da pregação, da oração, do bom conselho ou do bom ensino, como alternativas indispensáveis à vida perfeita. Nesse sentido, toda fala tinha caráter profético, já que o homem só falava corretamente quando era Deus quem falava por sua boca (BÉRIOU; BOUDET; ROSIER-CATACH, 2014, p. 4).

Nessa esteira, a fala tornou-se, na Baixa Idade Média, um forte mecanismo de externalizar verbalmente as dores do mundo, bem como um fecundo meio de aprendizagem, já que por meio da repetição oral das lições prescritivas durante a confissão auricular, o fiel aprendia e naturalizava um determinado conjunto de valores referentes à doutrina cristã (TEODORO, 2016, p. 1). De fato, a confissão tinha força operacional própria: dizia, mostrava, expulsava e libertava; assim com as palavras que o fiel confessava, o próprio diabo era expulso do corpo; o próprio trabalho de dizer a verdade sobre si mesmo durante a confissão era, portanto, um 


\title{
O poder na Idade Média
}

A palavra como remissão da alma (Portugal no século XV)

exercício de mortificação (FOUCAULT, 2019, p. 126). Em um momento como a Idade Média, em que a maioria da população era composta por iletrados, e as relações sociais eram perpassadas por pactos e compromissos pessoais, bem como alicerçadas em convenções de caráter oral, a palavra era ao mesmo tempo valorizada e mantida sob suspeita (MACEDO, 2003, p. 88-107).

A relação entre o sagrado e a palavra é tão antiga quanto o Antigo Testamento, já que segundo a crença medieval, pautada nas Sagradas Escrituras, o universo teria começado como uma resposta ao comando verbal de Deus. Portanto, a palavra tinha poder miraculoso, como a própria criação, dado que a palavra de Deus foi a expressão da atividade criadora: "Deus disse: Exista a luz. E a luz existiu" (BíBLIA, Genesis 1, 3), do mesmo modo, pela palavra do Senhor os céus foram feitos, assim como pelo sopro de sua boca foram feitos seus exércitos (BíBLIA, Salmo 33, 6). Desse modo, a palavra de Deus não é apenas significativa pelo que diz e produz, mas também porque serve de diálogo entre Deus e o homem. Obediente à palavra, o homem, por sua vez, se realiza no mundo como imagem de Deus (GONZÁLEZ NúNEZ, 1999, p. 564-575), como bem sintetiza Ludolfo de Saxônia, em obra que foi traduzida e impressa no período aqui em questão:

\begin{abstract}
Abre Senhor também a minha boca muda, desfazendo os meus pecados por enviamento da Tua graça, e soltando a minha língua para apregoar os teus louvores por tal que recebida a graça de falar acuse a mim mesmo e louve a $\mathrm{Ti}$ e que [eu] edifique e faça proveito ao próximo e pregue a verdade. Amém (SAXÔNIA, 2011, p. 414).
\end{abstract}

Além disso, a doutrina cristã da Encarnação postulou ainda mais essa ideia, a partir da noção de Cristo como Palavra encarnada (BÍBLIA, João 1, 14): “no princípio de toda nossa intenção deve ser Deus, porque no princípio era a palavra: e Deus era palavra [...] Depois que o evangelista - Jesus Cristo - declarou ser ou gerar do verbo" (SAXÔNIA, 2011, p. 33-34). Dito de outro modo, a palavra foi feita carne, e morou em 


\section{O poder na Idade Média}

Eduardo Lima de Souza

nós, e assim todo fiel pode contemplar a glória do único filho do Pai cheio de graça e de verdade (MACHADO, 2008, p. 34). A Palavra tornou-se carne e viveu em nós, para que pudesse nos comunicar a palavra divina, por meio de todos os sentidos do corpo. Portanto, toda palavra deve ser uma revelação do divino que vem fluir dos lábios humanos ao mundo para testemunhar a Boa Nova. Mediador entre o espírito e a carne, entre a consciência e o mundo, a fala é ao mesmo tempo pensamento, emoção e ação. O fiel deve recriar a palavra a todo momento para servir como intermediária entre o mundo invisível, que ele carrega dentro de si - seus pensamentos -, e o mundo visível, que se estende diante dele, obrigando um a penetrar o outro para torná-lo, por assim dizer, seu testemunho (LAVELLE, 2005, p. 39-53).

O poder da palavra era visto como algo efetivo na sociedade medieval, daí a insistência dos compiladores em frequentemente regular os fiéis a partir de um vasto campo semântico de violência verbal pautada nos rudimentos da fé cristã. O modelo era bíblico, pois o próprio Deus havia amaldiçoado pela palavra, a serpente responsável pelo pecado de Adão e Eva, assim como a maldição de Noé lançada sobre Caim era considerada a origem do fenômeno social da escravidão (FRANCO, 1996, p. 115). Dessa forma, o dom da palavra atribuída aos homens tornou-se a conexão imediata entre o mundo terreno, corrupto e corruptível, e o mundo transcendental, perfeito e eterno (BAIKA, 2007, p. 15): "assim como o corpo não pode viver sem o comer material, assim [não pode viver] a alma sem a palavra de Deus" (MACHADO, 2008, p. 60), porque a palavra de Deus "pode salvar as almas no presente e no vindouro. No presente [salva] da morte da culpa" (Ibid., p. 240-241).

Embora fosse uma parte do corpo difícil de controlar, a língua podia ser um precioso instrumento para a salvação, a exemplo da premissa bíblica do livro de Provérbios: “Do fruto da boca de cada um fartará o seu ventre; dos renovos dos seus 


\section{O poder na Idade Média}

\section{A palavra como remissão da alma (Portugal no século XV)}

lábios se fartará. A morte e a vida estão no poder da língua, e aquele que a ama comerá do seu fruto" (BÍBLIA, Provérbios 18, 20-21). Pelo mero ato de dizê-la, removendo-a da interioridade secreta da consciência, a má ideia perde sua força de sedução e seu poder de enganar quando a palavra é pronunciada (FOUCAULT, 2019, p. 115). Como principal meio de que dispõem os homens para exprimir o que thes passava no espírito, era ela, inclusive, que podia derrotar o diabo, pois, por seu intermédio, se discordava do demônio e se concordava com Cristo (SAXÔNIA, 2011, p. 259).

A comunidade cristã, como se vê, nasceu em torno da palavra, e continuou vivendo da palavra, assim como escutou Abraão seu chamado: "Ora, o Senhor disse a Abrão: sai da tua terra, e da tua parentela, e da casa de teu pai para a terra que eu te mostrarei" (BÍBLIA, Gênesis 12, 1). Do mesmo modo, pela palavra, Jesus chama seus discípulos: "Vinde após mim, e eu vos farei pescadores de homens" (BÍBLIA, Mateus 4, 18). Entretanto, a força da palavra que parte do chamado de Deus aos homens, por meio sobretudo dos pregadores e curas de almas, partia da própria resposta dos que se dispõem a continuar escutando Sua palavra e querendo viver dela. Segundo o teólogo, pela voz da pomba ${ }^{1}$ - o Espírito Santo -, Deus possibilitou que a boca humana pudesse louvá-lo e dar-Ihe graças (SAXÔNIA, 2011, p. 192). Ao fim e ao cabo, os pregadores e moralistas da Idade Média procuraram provocar, com suas palavras, emoções, tais como o ódio pelos pecados ou o amor a Deus, esperança de salvação ou medo do julgamento divino (BÉRIOU, 2014, p. 255).

Acometido pelo pecado, o fiel deveria imediatamente buscar um sacerdote e

\footnotetext{
1 "E ocorreu que, quando todo o povo estava sendo batizado, da mesma maneira Jesus o foi; e no momento em que Ele estava orando, o céu se abriu e o Espírito Santo desceu sobre Ele em forma corporal, como uma pomba. E do céu surgiu uma voz: "Tu és o meu Filho amado; e em ti me agrado sobremaneira". Lucas 3, 21-22. BíBLIA do Peregrino. São Paulo: Paulus, 2011, p. 2188.
} 


\section{O poder na Idade Média}

Eduardo Lima de Souza

mostrar a ele "a lepra de sua alma por confissão da boca" (SAXÔNIA, 2011, p. 448449). Por meio deste jogo entre o sentimento íntimo e a sua exibição, descobria-se a doença encoberta, na esperança de obter perdão (Ibid., p. 228.), em outras palavras, segundo o tratadista, não se aproveitava em nada a contrição do coração se não se seguisse a confissão pela boca, uma vez que a confissão promove a saúde das almas e destrói os pecados. Além disso, tinha ela o potencial de restaurar as virtudes e abrir as portas do Paraíso, dado que se apresentava como uma forma de combate frontal aos próprios demônios (Ibid., p. 230). Desse modo, a palavra pronunciada na confissão servia para defender o coração do fiel, de forma que, nas orelhas, se faria uma sebe ${ }^{2}$ de espinhos e a boca seria aberta como uma porta. Melhor dizendo, as fechaduras nas orelhas seriam para que todos se mantivessem livres das tentações e firmes na fé e atentos à vigilância de Deus (SAXÔNIA, 2011, p. 487).

Nas palavras do compilador Clemente Sánchez de Vercial, o confessor deveria admoestar e induzir o pecador por boas palavras, “doces na contrição e arrependimento, dando-Ihe a entender quantos bens Deus neste mundo lhe tem feito e faz, e como o nosso salvador Jesus Cristo desceu dos céus à terra e morreu por nós, pecadores" (SANCHEZ , 2010, p. 245). Em outra altura, assevera que o ritual da penitência devia conter três importantes premissas, a contrição, a confissão pela boca e a satisfação pelas obras, porque a verdadeira penitência constrange e faz o pecador sofrer todas as coisas de boa vontade, e com o coração contrito confessar pela boca, e transpor nas obras toda sua humildade. Pela virtude das "chaves" (BÍBLIA, Mateus, 16, 19), a Igreja detinha o poder de perdoar ou não os pecados na Terra a partir da absolvição concedida ao pecador no rito da confissão, poder este que Jesus

\footnotetext{
2 "Cerca feita de arbustos, paus, espinhos ou ramos secos". SEBE. In: MACHADO, José Barbosa. Dicionário dos primeiros livros impressos em língua portuguesa. Braga: Edições Vercial, 2015, vol. IV, p. 189.
} 


\section{O poder na Idade Média}

\section{A palavra como remissão da alma (Portugal no século XV)}

transmitiu aos apóstolos e que, posteriormente, teria sido atribuído aos papas (BECHTEL, 1987, p. 62). Desse modo, a confissão não deveria ser feita a qualquer pessoa, mas somente aos sacerdotes, considerados portadores da "chave da ciência e de autoridade" (SAXÔNIA, 2011, p. 448-449). Assim, quanto mais os fiéis confessassem "a torpeza de seus pecados, por esperança de receber perdão, tanto ganhará mais ligeiramente a graça de receber remissão" (Ibid., p. 230), pois, ao mesmo tempo que a ação do pecado afetava todos os homens e o destino eterno de cada um deles, a obra da graça de Cristo convocava a todos os fiéis à justificação (GARCIA, 1971, p. 57-58), através do sacramento da penitência.

Essa reconstrução de si mesmo, por meio da verbalização dos pecados, a partir dos rituais da confissão, era vista como um exercício terapêutico que só funcionaria se fosse praticado regularmente do início ao fim da vida, já que o cristão nunca poderia se considerar uma obra concluída, a ponto de sozinho enfrentar suas aflições (TEODORO, 2017, p. 57). No entanto, apesar de a teologia corrente insistir que a confissão deveria ser dirigida exclusivamente a um sacerdote, na ausência deste, ela poderia excepcionalmente ser feita a um leigo, dado que havia uma crença no poder de expiação da palavra e seu potencial salvífico; poder manifesto igualmente nas missas rezadas às almas do purgatório (FRANCO, 1996, p. 114), como quando nas missas de finados, destinadas àqueles que estão no purgatório, as palavras pronunciadas pelos vivos serviam para que as almas do purgatório fossem absolvidas das penas (SANCHEZ, 2010, p. 205).

A palavra mostrava-se eficaz não porque era enunciada em nome do próprio locutor - do fiel -, mas em nome de Cristo. Era pelo anúncio da Boa Nova, essencialmente feito através da pregação, que a Igreja crescia, se consolidava e se difundia. Pelas palavras da pregação, o fiel estabelecia e intensificava, na fé, sua 


\section{O poder na Idade Média}

Eduardo Lima de Souza

relação com Deus e apelava à conversão, como meio indispensável de redenção individual e salvação de todos (MARQUES, 2002, p. 317). Dito de outro modo, a palavra de Deus é como semente, "porque a semente que se semeia sem que se embrulhe [faz] a terra ficar sem fruto", assim como as palavras de Deus que se ouvem na pregação sem que se guarde na memória. Porque diz Davi no livro de Salmo, capítulo 118: "em meu coração são escondidas tuas palavras porque não preguei a ti, segundo a semente [que] sem o benefício do sol não cresce, assim a palavra de Deus pregada sem que a graça de Deus ajude", e esta é a razão, segundo o letrado, pela qual se reza no início do sermão pedindo a graça e invocação dos santos; enfim, como a semente é matéria do pão para recriar o corpo, assim a palavra de Deus é matéria da pregação pera recriar a alma (MACHADO, 2008, p. 55). Para tanto, a Virgem Maria concebeu aquele que é verdadeiro sacrifício pelo que há de se celebrar e pelo qual os apóstolos e mártires deram testemunho deste sacrifício por palavra e por derramamento de sangue (SANCHEZ, 2010, p, 172), porque "crer [em] Deus é crer nas [palavras] que são ditas [...] pelos profetas" (Ibid., p. 41).

Nessa interpretação, o poder da palavra era derivado de uma palavra dita por Deus, por Cristo, um santo ou um pregador, uma vez que o próprio Cristo teria conferido poder contra os demônios aos apóstolos e aos discípulos (BÍBLIA, Atos dos Apóstolos 3, 16; Lucas 10, 19), assim, o pregador é aquele que assegura um processo de inserção dos indivíduos considerados em desacordo com a ética ou a moral religiosa, que acolhe novamente os desviados para restaurar a unidade. A pregação representa, através da figura do pregador e pela mediação de sua palavra, a conciliação da comunidade consigo própria e enuncia não só a perspectiva de um destino escatológico ${ }^{3}$ de incidência individual, mas também a recuperação do sentido

\footnotetext{
3 “Escatologia diz respeito ao destino dos indivíduos na história redentora. Visto que Deus é o Senhor
} 


\section{O poder na Idade Média}

\section{A palavra como remissão da alma (Portugal no século XV)}

de uma existência comum de ordenação social, pautada pelos valores morais e religiosos, a partir, sobretudo, da construção da palavra pronunciada (NASCIMENTO, 1988, p. 5).

Compreende-se, pois, que a pregação adquiriu um caráter escatológico e soteriológico ${ }^{4}$, já que dela procede a mensagem que salva. A principal ferramenta do pregador é a palavra, de que se sente servidor. Pela palavra, serve o homem a Deus, atuando como mediador de sua comunicação (GONZÁLEZ NÚNEZ, 1999, p. 564-575). Entretanto, convém que os pregadores busquem os lugares onde a palavra de Deus possa mais fazer fruto e não aqueles onde possam melhor e mais viçosamente estar (SAXÔNIA, 2011, p. 190). Por esta razão é que o compilador do Tratado de Confissom recomenda que os fiéis devam frequentemente ir à Igreja aos domingos e festas, devotamente e honestamente, para ouvir as missas e as horas e as pregações e, além disso, aprender a santa doutrina da fé católica e depois que colocarem em prática tais ensinamentos, devem socorrer os pobres mingados, lazerados ${ }^{5}$ e enfermos e encarcerados e cumprir as obras de misericórdia, "segundo nossas condições" (MACHADO, 2003, p. 44). De fato, é pela pregação que homens e mulheres decidem seguir a Cristo, e é este seguimento que, na terra, constrói uma comunidade espiritual, a Igreja (MIATTELO, 2014, p. 113).

Neste processo, concomitante à função de anunciar o evento da salvação, a Igreja também se preocupou com a função de exortar e de ensinar. Desse modo,

da história, a consumação da obra redentora de Deus, incluirá a redenção da própria história". Novo dicionário da Bíblia. São Paulo: Vida Nova, 2006, p. 422.

4 "Soteriologia". Soteriologia é uma parte da teologia que trata da salvação do homem. SOTERIOLOGIA. In: NOVO dicionário Aurélio da língua portuguesa. Rio de Janeiro: Editora Nova Fronteira, 1999, p. 1888.

5 "Leproso". LAZERADO. In: MACHADO, José Barbosa. Dicionário dos primeiros livros impressos em língua portuguesa. Braga: Edições Vercial, 2015, vol. III, p. 97. 


\section{O poder na Idade Média}

Eduardo Lima de Souza

segundo o Sacramental, a primeira obra de misericórdia é "ensinar os ignorantes". ${ }^{6}$ Assim, devemos ensinar os simples que não sabem o que fazem e "não devemos ser escassos de ensinar o que sabemos", sobretudo os prelados ${ }^{7}$ e os que tem curas $^{8}$ de almas, porque "devem ensinar a seu povo e a seus súditos a fé e a crença de Jesus Cristo e os mandamentos de Deus, e os sacramentos da Santa Madre Igreja" (SANCHEZ, 2010, p. 107). Em outro fragmento, o letrado chama a atenção para as próprias palavras de Jesus Cristo direcionadas a seus discípulos, ao estabelecer o sacramento do batismo (BÍBLIA, Mateus 28, 19): "ide por todo o mundo e ensine todas as gentes, batizando-as em nome do Pai e do Filho e do Espírito Santo" (ibid., p. 120).

Por esta razão foi que os três pastores, quando viram o menino Jesus na manjedoura, a partir do "conhecimento da humanidade viveram o conhecimento da divindade. E não se turvaram de ver tanta pobreza, antes foram confirmados na fé". E começaram, segundo o compilador dos Evangelhos e Epistolas com suas Exposições em Romance, a contar a Maria, a José e a todos que viram, "os cantares dos anjos que ouviram, e todos os que ouviram se maravilharam do que lhes disseram os pastores". Não somente se maravilharam do mistério da encarnação, mas ainda da quantidade de testemunho dos pastores "que com simples fala pregaram a verdade" (MACHADO, 2008, p. 33): o que disse o anjo Gabriel à Virgem Maria e o que ela tinha experimentado, e tudo mais que ouviram os pastores. A verdade tem como sinônimo, na linguagem de Jesus, o caminho e a vida. No caminho da vida é que se torna real e

\footnotetext{
6 "Que ou aquele que ignora: desconhecedor: simples". IGNORANTE. In: MACHADO, José Barbosa. Dicionário dos primeiros livros impressos em língua portuguesa. Braga: Edições Vercial, 2015, vol. III, p. 8.

${ }^{7}$ Prelado. Superior de uma diocese, convento ou abadia: bispo. PRELADO. In: MACHADO, José Barbosa. Dicionário dos primeiros livros impressos em língua portuguesa. Braga: Edições Vercial, 2015, vol. III, p. 539.

8 "Múnus paroquial de um sacerdote". CURA. In: MACHADO, José Barbosa. Dicionário dos primeiros livros impressos em língua portuguesa. Braga: Edições Vercial, 2015, vol. I, p. 608.
} 


\section{O poder na Idade Média}

\section{A palavra como remissão da alma (Portugal no século XV)}

se aperfeiçoa a verdade da palavra, pelo testemunho dos que vivem dela.

Portanto, falar é ensinar. O Senhor consentiu que aos que falam e ensinam boas coisas, "fossem dadas causas e azo ${ }^{9}$ de consolação e remédio e paciência contra os maliciosos", ${ }^{10}$ que fossem contra o que os discípulos de Cristo dissessem, pois antes das palavras de Cristo os discípulos também murmuravam, e sabendo Cristo que eles murmuravam entre si, "solveu"1 aquele que os movia à murmuração e declarou-lhes que [fossem] escandalizados" (SAXÔNIA, 2011, p. 61). Por isso, ensinam os Evangelhos e Epístolas, que o Espírito Santo procede do Filho, Jesus Cristo, que promete enviar o espírito que "ensinará toda a verdade, mas, pelo contrário, o espírito maligno ensina toda [a] mentira" (MACHADO, 2008, p. 93). Em contrapartida, é importante ressaltar que ensinar somente por palavras e não por obras é vaidade, uma vez que, segundo diz São Bernardo: "coisa de maravilhar é a língua falar muito e a mão ser ociosa [em] ensinar claramente e a vida ser escurenta". ${ }^{12}$

Nesse contexto, na relação religiosa, o diálogo é suscitado por Deus, dono de todas as iniciativas; e a iniciativa do homem está na sua resposta. O fiel deve então responder à palavra que the oferece o Pai, suscitando o diálogo inter-humano, para tornar-se a imagem de Deus. Segundo a Primeira Carta de Timóteo, os homens devem orar em qualquer lugar, elevando suas mãos puras, livres da ira e da discórdia (BÍBLIA, Primeira Carta a Timóteo 2, 8). Sem a fala prévia de Deus e sem a

\footnotetext{
9 "Motivo: causa". AZO. In: MACHADO, José Barbosa. Dicionário dos primeiros livros impressos em língua portuguesa. Braga: Edições Vercial, 2015, vol. I, p. 290.

10 "Que ou o que tem predisposição para o mal; maldoso". MALICIOSO. In: MACHADO, José Barbosa. Dicionário dos primeiros livros impressos em língua portuguesa. Braga: Edições Vercial, 2015, vol. III, p. 160.

11 "Soltar; desligar; desatar; resolver". SOLVER. In: MACHADO, José Barbosa. Dicionário dos primeiros livros impressos em língua portuguesa. Braga: Edições Vercial, 2015, vol. IV, p. 267.

12 "Escurecer; tornar escuro: perder a claridade". ESCURENTAR. In: MACHADO, José Barbosa. Dicionário dos primeiros livros impressos em língua portuguesa. Braga: Edições Vercial, 2015, vol. II, p. 361.
} 


\section{O poder na Idade Média}

Eduardo Lima de Souza

comunicação de seu espírito com o espírito humano, o homem não seria capaz nem de chamar Deus de pai. A prova mais convincente de que Deus fala e se revela está na resposta do homem na oração, expressa em palavras (GONZÁLEZ NúNEZ, 1999, p. 564-575).

A oração por palavra, que se faz pela boca, deve ser feita pelos eclesiásticos e por todos os outros cristãos, porque são obrigados a fazer por estabelecimento e constituições da Igreja" (SANCHEZ, 2010, p. 292-293). Orar consiste na atitude profunda de ouvir em sintonização com o Deus que fala. É deixar-se encontrar pela palavra de Deus e orientar-se por sua vontade, assim, toda oração ocorre sob o pressuposto de que Deus pode falar, já que falou pela história de seu povo (SCHALTER, 1993, p. 594-597). A oração não é palavra afastada da vida, é a vida levada

ao diálogo. Assim, reveste-se das formas básicas de súplica, de ação de graças e louvor. Em outras palavras, admoestar o tratadista de que se deve usar "a ligadura da língua para oração, para a edificação do próximo e para sua própria ensinança para a confissão do pecado e louvor de Deus" (MACHADO, 2008, p. 126).

Tendo em vista que a mesma língua que condenava podia salvar, convinha que a oração feita pelo sacerdote na igreja fosse "notificada", e isso não se poderia fazer se não houvesse palavras. Portanto, era necessário que, se possível, a oração fosse feita por palavras, tanto a oração feita por si mesma quanto a oração direcionada ao próximo. Mesmo aquelas orações em que não se usavam palavras, estas deveriam ser feitas por três razões: a primeira, por devoção, para assim mover e induzir a vontade do fiel de dentro para fora; a segunda, para que a palavra desse a entender que o homem deve servir a Deus de corpo e alma; a terceira, para dar a entender o grande desejo que sai do corpo e da alma pela oração (SANCHEZ, 2010, p. 290-291). A externalização verbal era, pois, uma virtude purificadora que tinha o poder de 


\section{O poder na Idade Média}

\section{A palavra como remissão da alma (Portugal no século XV)}

dissipar as ilusões e evocar os enganos internos, isto é, quanto mais um pensamento tendesse a escapar da externalização das palavras que tentam compreendê-lo, mais necessário seria persegui-lo e confessá-lo. A vergonha, que se manifesta quando as palavras são externalizadas sobre o que se está oculto, é uma marca indiscutível do mal que deve ser assim desafiado e contido, para que pela palavra, que traz à luz Satanás, o pecado seja condenado às trevas e mergulhado na impotência (FOUCAULT, 2019, p. 125).

Em contrapartida, é recomendado, pelo autor Ludolfo de SAXÔNIA, em sua obra Vita Christi, que os fiéis façam suas orações a Deus com devoção e piedade, sem a necessidade de serem palavrosos ${ }^{13}$, já que uma coisa é "muita verba ${ }^{14}$ e outra, haver prolongado e perseverado desejo, porque muitas vezes este negócio de orar se faz melhor por gemidos que por palavras e mais se faz com choros que com falamentos". ${ }^{15} \mathrm{Em}$ seguida, o tratadista complementa que estas atitudes devem ser tomadas em orações singulares e privadas e que se faz por vontade, porque as orações públicas devem ser feitas por "palavras, de guisa que possam ser ouvidas por outros" (SAXÔNIA, 2011, p. 337-338). Se ainda, porventura, o fiel não se sentir idôneo ${ }^{16}$ para fazer suas orações, é recomendado que ele busque alguns irmãos espirituais que o ajudem com orações e, assim se creia que será mais ajudado pelos rogos e orações de muitos, que pelos próprios rogos e orações somente (Ibid., p. 270).

Enfim, a oração é a resposta à palavra prévia de Deus, por isso, o letrado

\footnotetext{
13 "Que fala muito: tagarela". PALAVROSO. In: MACHADO, José Barbosa. Dicionário dos primeiros livros impressos em língua portuguesa. Braga: Edições Vercial, 2015, vol. III, p. 382.

14 "Verbosidade: palavreado". VERBA. In: MACHADO, José Barbosa. Dicionário dos primeiros livros impressos em língua portuguesa. Braga: Edições Vercial, 2015, vol. IV, p. 427.

15 "Ato ou efeito de falar: fala: discurso". FALAMENTO. In: MACHADO, José Barbosa. Dicionário dos primeiros livros impressos em língua portuguesa. Braga: Edições Vercial, 2015, vol. II, p. 442. 16 "Apto: capa/: adequado: honesto". IDÓNEO. In: MACHADO, José Barbosa. Dicionário dos primeiros livros impressos em língua portuguesa. Braga: Edições Vercial, 2015, vol. II, p. 6.
} 


\section{O poder na Idade Média}

Eduardo Lima de Souza

declara que não se pode regrar ou limitar quantas devem ser as palavras de oração, mas devem-se usar tais e tantas quantas forem necessárias para "demover ${ }^{17}$ a devoção" e se, por acaso, o fiel vir ameaçadas, pela multiplicação das palavras, a memória e a devoção do que pede, embargando a devoção por esse excesso, então "deve cessar as palavras e orar a Deus com afeito de vontade" (SAXÔNIA. 2011, p. 377). Mas permanece o poder das palavras, pela voz ou pela fala da boca ou pela memória daquilo que queremos pedir a Deus em oração. Melhor seria a oração pela palavra e pela boca, pois pode tirar a preguiça do fiel; e se o homem sempre orasse caladamente, muito de ligeiro adormeceria e não haveria lembrança daquilo que pedia (Ibid., p.377).

No que tange mais especificamente aos louvores a Deus, era recomendado aos fiéis que nunca se vangloriassem, mas unicamente reconhecessem em Deus todo o bem, pois não só pelo costume há de se dizer "graças a Deus", nem somente com os "beiços", mas assim o faça e conheça as entrelinhas do coração (Ibid., p.186), porque qualquer palavra sábia que ouvir o homem sensato, ele a louvará e dela se aproveitará, todavia, a um homem voluptuoso ela desagradará, e ele a arremessará para trás de si (BÍBLIA, Eclesiastes 21, 18). Nesse contexto, o compilador Guilherme Parisiense admoesta os fiéis para que não se embriaguem de vinho, porque podem ser levados ao pecado da luxúria, por isso, os convida a se encherem do Deus de Espírito Santo, "falando com [o próximo] em salmos e louvores e cantares espirituais, [e] cantando e dizendo salmos em vossos corações ao senhor" (MACHADO, 2008, p. 273).

Para tanto, quando o pregador canta algumas vezes cantigas de alegria, ensina

\footnotetext{
17 "Persuadir: convencer: impelir". DEMOVER. In: MACHADO, José Barbosa. Dicionário dos primeiros livros impressos em língua portuguesa. Braga: Edições Vercial, 2015, vol. II, p. 64.
} 


\section{O poder na Idade Média}

A palavra como remissão da alma (Portugal no século XV)

e prega sobre as virtudes e os prazeres eternais, e aqueles que ouvem devem bailar e com prazer saltar fora dos vícios e pecados e algumas vezes fazer pranto, quando o pregador repreende os vícios e fala sobre as penas e dores do inferno, então os que ouviram devem chorar e fazer penitência (SAXÔNIA, 2011, p. 586) e, assim, recomenda o tratadista que houvesse de comover de não serem ingratos, mas que dessem graças a Deus e, sobretudo, que anunciassem e confessassem os benefícios que Dele recebem, porque Cristo mostra que, das maravilhas e milagres, devem dar louvores unicamente a Deus, porque os homens, enquanto têm enfermidades, sempre se lembram de Deus, e depois que [estão] seguros e livres da doença são cercados da dor da preguiça e não se lembram do que deveriam testemunhar (Ibid, p.447).

Os compiladores destes incunábulos também chamam a atenção para outra prática verbal, a do bom conselho, para que mutuamente os fiéis se alertassem dos bons costumes e da boa vida, aconselhando seu irmão para a saúde de sua alma e para que tivessem cuidado dos perigos e das tribulações, aconselhando-os quando necessário fosse (SANCHEZ, 2010, p. 338-339). O bom conselho era tão importante que Ludolfo de SAXÔNIA, o autor da ora impressa Vita Christi, recomenda ainda que os fiéis recorram "a teu sabedor e discreto confessor" para obter a graça do bom conselho, ajuda e consolação nas tentações muito secretas e muito escondidas. Em seguida, acrescenta que este remédio - o bom conselho - louva muitos santos, pois conseguiam se livrar das tentações, por sua humildade e simplicidade, ao "demandar conselho e ajuda sobre suas tentações" (SAXÔNIA, 2011, p. 401). Nesse sentido, o conselho verdadeiro leva a escolher o bem, deixar o mal e guardar os perigos deste mundo que podem acontecer. Entretanto, o letrado assevera que primeiramente o fiel deve castigar a si mesmo, visto que a caridade deve ser ordenada a si mesmo 


\section{O poder na Idade Média}

Eduardo Lima de Souza

antes de corrigir e castigar o outro que pecou, mas não por palavras ásperas nem por ódio nem malquerença, mas por caridade e por boa irmandade (SANCHEZ, 2010, p. 120).

Em linhas gerais, o encaminhamento das boas palavras se dá pelos frutos da boca, como a oração, a pregação, do dar graças a Deus, e sobretudo, pela prática do bom conselho, correção ao irmão que anda errado e ensino ao desensinado (SAXÔNIA, 2011, p. 436). Nesse sentido, as boas palavras são o caminho para o aperfeiçoamento da alma (Ibid., p. 399), elevando os homens ao reino de abastança, através da confissão, do ensino, da oração, da pregação e do conselho, como o conselho dado por Jesus aos discípulos por meio da parábola do homem rico: "se queres ser perfeito vai, vende tudo o que tens e dá-o aos pobres, e terás um tesouro no céu; e vem, e segue-me" (BÍBLIA, Mateus 19, 21). Portanto, não é santo aquele que "dirige" a si mesmo, mas quem se deixa "dirigir" por Deus, contra as armadilhas que atormentam seu pensamento e ocultam a origem e as consequências do mal. Era preciso um recurso externo, a graça divina, sem a qual nada prospera, para que o homem fosse capaz de caminhar em direção à vida perfeita (FOUCAULT, 2019, p. 125).

\section{Considerações finais}

Em meados do século XV em Portugal, com o aparecimento da imprensa e o revigorar da confissão auricular, estatuída desde o século XIII - a partir do IV Concílio de Latrão de 1215 -, levou-se a cabo o estabelecimento regular e frequente de prescrições específicas para o cuidado da alma. Em consequência disso, obras de cunho catequético, tais como os aqui examinados manuais de confissão, contribuíram para ordenar e definir ainda mais a doutrina cristã, funcionando igualmente como canalizadores dos bons costumes. Entre as prescrições mais recorrentes estavam 


\section{O poder na Idade Média}

\section{A palavra como remissão da alma (Portugal no século XV)}

aquelas associadas aos pecados cometidos oralmente e suas respectivas variantes, tais como a blasfêmia, o murmúrio, o falso testemunho, o juramento e a mentira. Em paralelo à condenação dos usos impróprios das palavras, difundiu-se uma ampla proposta pedagógica ancorada no enaltecimento de algumas práticas consideradas virtuosas acerca dos rudimentos da fé católica: a verbalização dos pecados no momento da confissão, a pregação, a oração, o bom conselho e o bom ensino, como verdadeiras ferramentas de aperfeiçoamento da alma. Dessa forma, o contato com o divino dava-se, sobretudo, pela palavra falada, o que parece ter sido intensificado com a institucionalização da confissão auricular; a introdução da língua vernácula dando a conhecer os principais rudimentos da fé católica; a invenção da imprensa e a propagação principalmente de obras de cunho moral e pedagógico; e, por fim, a força da pregação no período, ocupando lugar de destaque, especialmente com uma grande adesão e intensificação das ordens mendicantes no território da Península Ibérica.

Criada por Deus com o mundo, veiculada por ele e recebida por nós, a palavra devia, como propuseram os primeiros escritos impressos, estar sempre a serviço de Deus nos textos sagrados e nos lábios que experimentam a glória de Deus (CHRÉTIEN, 1998). Dito de outro modo, a palavra é um alimento sensorial da alma, uma ponte entre o mundo terreno e o mundo transcendental, uma vez que a relação com Deus só poderia ser catalogada a partir dos sentidos. De fato, os fiéis medievais eram sensibilizados pelos sentidos, como a própria degustação do corpo e do sangue de Cristo no momento da transubstanciação; assim, ainda que a palavra pronunciada não seja um dos cinco sentidos, ela complementa os sentidos do fiel medieval, porque era pela palavra falada que essas prescrições tomavam corpo. Portanto, se a palavra é um alimento da alma, metaforicamente pode ser sentida, degustada e 


\section{O poder na Idade Média}

Eduardo Lima de Souza

ouvida; por ela, a própria fé e as virtudes podem ser experimentadas e provadas (PALAZZO, 2014, p. 59-91). Em suma, assim como o corpo não pode viver sem o alimento material, assim a alma não pode viver sem a palavra de Deus, porque dela procede a mensagem que salva. (MACHADO, 2008, p. 60).

Condenar a prática das más palavras e exaltar e incorporar a prática das boas palavras eram, pois, formas de reconciliar a alma com o corpo do fiel penitente. Por isso, as prescrições dos manuais de confissão concernentes à verbalização das palavras cumprem papel pedagógico de correção no Portugal quatrocentista; mas do que isso, os diferentes tratadistas referenciados neste trabalho foram-se apercebendo das mudanças sociais ocorridas no medievo e conduzindo-as de alguma forma, dado que os diferentes manuais só puderam responder de forma eficaz ao que ocorria por terem tido em conta essas mesmas mudanças (FERNANDES, 1990, p. 60). Com o percurso aqui traçado, tentamos demonstrar que Portugal se alimentou de um vasto patrimônio literário cristão e ajudou a nutri-lo. Sem perder seus elos fundamentais, a moral cristã una e dinâmica ganhou forma particular neste território, o que demostra que ela não parou de se construir e de se adaptar (VEYNE, 2011, p.107-116).

\section{Bibliografia}

Fontes

MACHADO, José Barbosa. Evangelhos e epístolas com suas exposições em romance. Edição e estudo. Braga: Edições Vercial, 2008, p. 256

MACHADO, José Barbosa. Tratado de Confissão: Edição Semidiplomática, Estudo Histórico e Linguístico. Braga: Edições Vercial, 2003-2010.

SANCHEZ, Clemente. Sacramental. Tradução de José Barbosa Machado. S/L: Vercial, 2005-2010. 


\section{O poder na Idade Média}

A palavra como remissão da alma (Portugal no século XV)

SAXÔNIA, Nicolau de. Vita Christi. Vol. I, II, III. Braga: Edições Vercial. Edição e estudo de José Barbosa Machado, 2011.

\section{Estudos}

AQUINO, Tomás de. Suma teológica. São Paulo: Edições Loyola, 2006.

BAIKA, Gabriella Ildiko. Lingua Indisciplinata: a study of transgressive speech in the "romance of the rose" and the "divine comedy". Pensilvânia: University of Pittsburgh, 2007. 326. Dissertação, Faculty of Arts And Sciences, 2006,

BAUBETA, Patrícia Anne Odber. Igreja, pecado e sátira na Idade Média Portuguesa. Portugal: Imprensa Nacional - Casa da Moeda, 1997.

BECHTEL, Guy. A Carne o Diabo e o Confessor. Lisboa. Edição: 1999BLOCH, M. L. B. A sociedade feudal. Lisboa: Edições 70, 1987.

BÉRIOU, Nicole; BOUDET, Jean-Patrice; ROSIER-CATACH, Irène. Le pouvoir des mots au Moyen Âge. Turnhout: Brepols, 2014, p. 14

BíBLIA do Peregrino. São Paulo: Paulus, 2017.

CASAGRANDE, Carla.; VECCHIO, Silvana. Les péchés de la langue. Pecado da Língua: Discipline et éthique de la parole dans la culture médiévale. Paris: Les Éditions du Cerf, 2007.

CHRÉTIEN, Jean-Louis Chrétien. L'arche de la parole: Épiméthée. Paris: Presses universitaires de France, 1998.

FERNANDES, Maria de Lurdes C. As Artes da Confissão: Em torno dos Manuais de Confessores do século XVI em Portugal. Humanística e teologia, Porto, p. 47-80, 1990.

FOUCAULT, Michael. Historia da sexualidad IV: Las confesiones de la carne. Madrid: Siglo XXI de España Editores, 2019.

. História da sexualidade: A vontade de saber. São Paulo: Paz e Terra, 2014.

FRANÇA. Susani S. L. Formas da verdade na poesia religiosa de Afonso X. In: LEÃO, 


\section{O poder na Idade Média}

Eduardo Lima de Souza

Ângela Vaz. Novas leituras, novos caminhos: Cantigas de Santa Maria de Afonso X, O Sábio. Belo Horizonte: Veredas \& Cenários, 2008.

FRANCO JÚNIOR, Hilário. A Eva Barbada. Ensaios de Mitologia Medieval. São Paulo: Editora da Universidade de São Paulo, 1996, p.

GARCIA, Gonzalo Florez. La reconciliación con Dios. Estudio teológico-pastoral sobre el sacramento de la penitencia. Madrid: Biblioteca de Autores Cristianos, 1971,

GILSON, Étienne. O Espírito da Filosofia Medieval. São Paulo: Martins Fontes, 2006.

GONZÁLEZ NÚNEZ, Angel. Dicionário de conceitos fundamentais do cristianismo. São Paulo: Paulus, 1999.

LAVELLE, Louis. La parole et l'ecriture. Paris: Éditions du Félin, 2005.

MACEDO, José Rivair. Disciplina do silêncio e comunicação gestual: os signa loquendi de Alcobaça. SIGNUM: Revista da ABREM, v. 5, 2003.

MACHADO, José Barbosa. Dicionário dos primeiros livros impressos em língua portuguesa. Braga: Edições Vercial, 2015, 4v.

MARQUES, José. A Pregação em Portugal na Idade Média. Alguns aspectos. Universidade de Sevilha. Via Spiritus, 2002.

MIATTELO. André Luis Pereira. O Pregador e a Sociedade: A luta pelo poder pastoral no ceio das cidades da Baixa Idade Média. Revista Territórios \& Fronteiras; Cuiabá, vol. 7, n. 2, jul.-dez., 2014.

NASCIMENTO, Aires Língua portuguesa e mediações religiosas. Revista ICALP, vol. 14, dezembro de 1988.

NOVO dicionário Aurélio da língua portuguesa. Rio de Janeiro: Editora Nova Fronteira, 1999, p. 1888.

PALAZZO, Éric. L'invention chrétienne des cinq sens dans la liturgie et l'art au Moyen Âge. Paris: Cerf, 2014.

PRODI, Paolo. Uma História da Justiça: do pluralismo dos foros ao dualismo moderno entre consciência e direito. São Paulo: Martins Fontes, 2005. 


\section{O poder na Idade Média}

A palavra como remissão da alma (Portugal no século XV)

SARAIVA, António José. História da literatura portuguesa. Lisboa: Publicações Europa - América, 1950.

SCHALTER, Hans. Dicionário de conceitos fundamentais de teologia. São Paulo: Paulus, 1993, p. 594-597.

TEODORO, Leandro A. Lições para o homem casado: Portugal - Séculos XIV-XVI. São Paulo: Editora Unifesp, 2016. . Instituições religiosas para o bem falar (Portugal/Castela - séculos XIV e XV). Revista Tempo, vol. 23, n. 1, p. 127-138, Jan./Abr. 2017.

VEYNE, Paul. Foucault: seu pensamento, sua pessoa. Tradução Marcelo Jaques de Morais. Rio de Janeiro: Civilização Brasileira, 2011. 